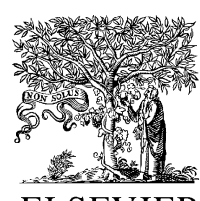

ELSEVIER

\title{
Short communication \\ A micrometeorological method for in situ denitrification measurements using acetylene inhibition
}

\author{
Jon S. Warland*, George W. Thurtell \\ Department of Land Resource Science, University of Guelph, Guelph, Ont., Canada N1G 2W1
}

Received 22 October 1999; received in revised form 22 March 2000; accepted 24 March 2000

\begin{abstract}
A method for acetylene inhibition measurements of denitrification in the field using micrometeorological techniques is presented. It is based on the monitoring of flux ratios from small $\left(<5 \mathrm{~m}^{2}\right)$ microplots. The method measures concentration profiles close to the surface, and from these the ratio of gradients, which can be assumed to be equal to the ratio of fluxes, is calculated. Acetylene has been shown to prevent the reduction of $\mathrm{N}_{2} \mathrm{O}$ to $\mathrm{N}_{2}$ by denitrifying bacteria, thereby increasing the flux of $\mathrm{N}_{2} \mathrm{O}$ by an amount equal to the $\mathrm{N}_{2}$ flux that would have been. By comparing the ratio of $\mathrm{N}_{2} \mathrm{O}$ fluxes from microplots with and without acetylene, an estimate of $\mathrm{N}_{2}$ production by denitrification was obtained. Field testing showed the technique to be practical and easily implemented. Under induced denitrifying conditions ratios of $\mathrm{N}_{2}: \mathrm{N}_{2} \mathrm{O}$ flux ranged from 0.42 to 31.4. () 2000 Elsevier Science B.V. All rights reserved.
\end{abstract}

Keywords: Acetylene inhibition; Denitrification; Micrometeorology; Tuneable diode laser trace gas analyser

\section{Introduction}

We present here a novel technique for field measurements of denitrification using acetylene $\left(\mathrm{C}_{2} \mathrm{H}_{2}\right)$ inhibition and micrometeorological techniques. Micrometeorological methods are generally preferred for measurements of trace gas fluxes under field conditions (Denmead and Raupach, 1993) because these methods measure the average flux from an area and do not interfere with the surface conditions. Further, micrometeorological methods are readily adapted for long-term monitoring, while retaining the ability

\footnotetext{
* Corresponding author. Tel.: +1-519-824-4120/6374; fax: +1-519-824-5730.

E-mail address: jwarland@1rs.uoguelph.ca (J.S. Warland)
}

to measure fluxes at fairly high temporal resolution ( $\sim 30 \mathrm{~min})$.

Estimates of $\mathrm{N}_{2}$ produced during denitrification frequently use a $\mathrm{C}_{2} \mathrm{H}_{2}$ block (e.g., Ryden et al., 1979; Duxbury, 1986; McConnaughey and Duxbury, 1986). Acetylene completely inhibits the functioning of nitrous oxide reductase at concentrations of about $1 \%$. This prevents the reduction of $\mathrm{N}_{2} \mathrm{O}$ to $\mathrm{N}_{2}$, thereby increasing the $\mathrm{N}_{2} \mathrm{O}$ flux by an amount equal to the $\mathrm{N}_{2}$ flux that would have been. Several significant problems have plagued the application of a $\mathrm{C}_{2} \mathrm{H}_{2}$ block technique to field studies in the past (Rolston, 1986). The effectiveness of the $\mathrm{C}_{2} \mathrm{H}_{2}$ block decreases over time, beginning a few days after application, due to microbial digestion of $\mathrm{C}_{2} \mathrm{H}_{2} \cdot \mathrm{C}_{2} \mathrm{H}_{2}$ also blocks nitrification, so that it may reduce denitrification by reducing the supply of nitrate. The $\mathrm{C}_{2} \mathrm{H}_{2}$-saturated 
area must be large enough to permit a flux measurement while simultaneous trials must be run with and without $\mathrm{C}_{2} \mathrm{H}_{2}$. The area must also be easily saturated with $\mathrm{C}_{2} \mathrm{H}_{2}$. Finally, it is important to minimise the disturbance of the soil and climate in order to replicate natural field conditions.

The present technique is designed to monitor emissions from plots on the order of $1 \mathrm{~m}$ radius (referred to as microplots). To do so we considered the ratios of mean concentration profiles close to the surface. By measuring $10-15 \mathrm{~cm}$ above the surface, we expect the concentration gradients to be dominated by fluxes originating within $\approx 1 \mathrm{~m}$ of the sample intakes. If the roughness and stability are equal over the two plots, the ratio of the fluxes can assumed to be directly proportional to the ratio of the gradients. Application of this method requires precise concentration measurements as well as a low air flow rate at the sample intakes in order to avoid disturbing flow patterns close to the surface. We accomplished this through the use of a sensitive tuneable diode laser trace gas analyser system (TDLTGAS).

To test the methodology, four-point profiles were measured simultaneously over two microplots in successive trials. Profiles were measured rather than two-point gradients to see at what height the profiles converged. Strongly denitrifying conditions were created through intensive irrigation and nitrate fertilisation to test the viability of this technique during major denitrification episodes. To control for possible mass-flow or oxygen displacement effects (which might increase denitrification by making the soil more anaerobic due to displacement of oxygen by $\mathrm{C}_{2} \mathrm{H}_{2}$ ) $\mathrm{CO}_{2}$ was injected in the second microplot. Effects of $\mathrm{CO}_{2}$ were tested for by running simultaneous plots with $\mathrm{CO}_{2}$ injection in one and no gas injection in the other. Finally, natural differences in $\mathrm{N}_{2} \mathrm{O}$ fluxes were tested for by running several trials of concurrent control plots (no gas injection).

\section{Methodology}

\subsection{Theory}

The flux, $F$, of a scalar in the lower atmosphere can be related to the gradient of concentration through a transfer coefficient
$F=-K \frac{\mathrm{d} c}{\mathrm{~d} z}$

where $c$ is the concentration of the scalar of interest, $z$ the height above ground and $K$ is the transfer coefficient. The transfer coefficient is a function of atmospheric stability, turbulence characteristics (represented by the friction velocity, $u_{*}$, in the surface layer) and height. To account for these, Eq. (1) can be written as

$F=\frac{-K\left(z, u_{*}\right)}{\psi\left(z / L_{\mathrm{O}}\right)} \frac{\mathrm{d} c}{\mathrm{~d} z}$

where $\psi$ is a stability correction and, therefore, a function of the Obukhov length $L_{\mathrm{O}}$.

It can readily be seen from Eq. (2) that the ratio of fluxes $F_{1} / F_{2}$ from two plots will equal the ratio of the gradients of concentration if $K$ and $\psi$ are equal over the two plots. If both plots have the same cover, the turbulence characteristics and stability should be the same over each plot at each height. Thus, a measurement of the ratio of gradients at equal heights is equivalent to a measurement of the ratio of the fluxes. Note that this holds true within a canopy as well, provided that the only source is the soil surface.

To measure $\mathrm{N}_{2}$ produced by denitrification, we used $\mathrm{C}_{2} \mathrm{H}_{2}$ inhibition to block the conversion of $\mathrm{N}_{2} \mathrm{O}$ to $\mathrm{N}_{2}$. Denitrification occurs under sufficiently anaerobic conditions, indicated by a low redox potential, and follows the path (Paul and Clark, 1989):

$\mathrm{NO}_{3}{ }^{-} \rightarrow \mathrm{NO}_{2}{ }^{-} \rightarrow \mathrm{NO} \rightarrow \mathrm{N}_{2} \mathrm{O} \rightarrow \mathrm{N}_{2}$.

$\mathrm{C}_{2} \mathrm{H}_{2}$ blocks the final step of this process, and therefore, the $\mathrm{N}_{2} \mathrm{O}$ flux from a plot with $\mathrm{C}_{2} \mathrm{H}_{2}$ should be equal to the $\mathrm{N}_{2}+\mathrm{N}_{2} \mathrm{O}$ flux from an untreated plot $\left(\sim \mathrm{C}_{2} \mathrm{H}_{2}\right)$. Thus, the ratio of fluxes from the treated and untreated plots should be

$\frac{F_{\mathrm{C}_{2} \mathrm{H}_{2}}}{F_{\sim \mathrm{C}_{2} \mathrm{H}_{2}}}=\frac{F_{\mathrm{N}_{2} \mathrm{O}+\mathrm{N}_{2}}}{F_{\mathrm{N}_{2} \mathrm{O}}}$

or, from the above discussion,

$\frac{F_{\mathrm{N}_{2}}}{F_{\mathrm{N}_{2} \mathrm{O}}}=\frac{[\Delta c / \Delta z]_{\mathrm{C}_{2} \mathrm{H}_{2}}}{[\Delta c / \Delta z]_{\sim \mathrm{C}_{2} \mathrm{H}_{2}}}-1$.

\subsection{Field trials}

Field testing was undertaken at the Guelph Turfgrass Institute in Guelph, Ont., Canada $\left(43.47^{\circ} \mathrm{N}\right.$, 
$80.38^{\circ} \mathrm{W}$ ) during September and October 1998. A large turfgrass field was available though this experiment only used $\approx 0.16$ ha. Two microplots of $1 \mathrm{~m}$ radius were treated and monitored at a time. Treatment for all plots consisted of heavy irrigation overnight and fertilisation with $200 \mathrm{~kg} \mathrm{~N} \mathrm{ha}^{-1}$ ammonium nitrate $\left(\mathrm{NH}_{4} \mathrm{NO}_{3}\right)$ the next morning. Measurements were begun immediately following fertiliser application. A sprinkler system composed of two ring sprinklers and needle valves to control the flow was used for irrigation. This system enabled us to focus the irrigation on an area only slightly larger than the microplot, ensuring that each plot was thoroughly saturated. The fertiliser was spread by hand over each microplot and irrigation continued afterward only long enough to dissolve the fertiliser.

The purpose of the irrigation was to create anaerobic conditions to encourage a strongly denitrifying soil environment. The addition of a nitrate-containing fertiliser guaranteed the presence of plenty of available nitrate for denitrification. Thus, conditions favourable for denitrification were created in each microplot.

Ratios of gradients from different treatments were examined. These were control/control, control/ $\mathrm{CO}_{2}$ injection, and $\mathrm{C}_{2} \mathrm{H}_{2}$ injection/ $\mathrm{CO}_{2}$ injection. All received irrigation and fertiliser, the $\mathrm{CO}_{2}$ and $\mathrm{C}_{2} \mathrm{H}_{2}$ treatments received injections of the respective gases, and the control treatments received no gas injection. The purpose of using $\mathrm{CO}_{2}$ in conjunction with the $\mathrm{C}_{2} \mathrm{H}_{2}$ injections was to control for any effects due to mass flow or oxygen displacement. The $\mathrm{CO}_{2} /$ control trials were conducted to examine any mass- or oxygen-displacement effects the $\mathrm{CO}_{2}$ might have on $\mathrm{N}_{2} \mathrm{O}$ emissions. The control/control trials were run to assess the variability of $\mathrm{N}_{2} \mathrm{O}$ emissions during denitrification. For the trials using gas injection, a simple system was used. A steel tube, $3 / 8$ in. o.d., was inserted in the centre of the microplot to a depth of $\approx 40 \mathrm{~cm}$. Tubing attached to the above-ground end delivered gas at a rate of $0.21 \mathrm{~min}^{-1}$. Though a more complex gas-delivery system (e.g., Ryden et al., 1979; McConnaughey and Duxbury, 1986) may be desired for future applications of this technique, this simple system was deemed sufficient to test the methodology. Gas injection began at the same time as the irrigation so that the gas would begin filling the air space in the soil at a depth, and meet the wetting front from the irrigation. Injection continued for the duration of the measurements. This was intended to improve the opportunity for the $\mathrm{C}_{2} \mathrm{H}_{2}$ to dissolve in the water.

\section{3. $\mathrm{N}_{2} \mathrm{O}$ measurements}

To monitor the gradients over each microplot we adapted a tuneable diode laser trace gas analyser system (Model TGA100, Campbell Scientific Inc., Logan, UT) to measure $\mathrm{N}_{2} \mathrm{O}$ concentration profiles (e.g., Simpson et al., 1997). For this study, sample intakes were switched every $7.5 \mathrm{~s}$ and averaging performed on the last $5 \mathrm{~s}$. The discarded $2.5 \mathrm{~s}$ are to allow for flushing of the sample cell. Mean concentration values for each intake were calculated at the end of each hour and stored to the hard disk drive of the control computer as well as sent to a printer.

The system was designed to monitor eight intakes which were attached to two frames with four intakes each. Each intake was sampled sequentially, allowing simultaneous monitoring of two plots. A spike on the bottom of each frame was inserted in the soil and the intakes held with approximate spacings of 1.5, 2.2 and $3.3 \mathrm{~cm}$ (bottom to top). The frames were inserted in the soil so that the lowest intake was approximately at the height of the grass, and the actual intake heights above the soil surface measured. During the trials, the lowest intake ranged from 6.0 to $10.6 \mathrm{~cm}$ and the intake heights averaged 7.7, 9.1, 11.4 and $14.7 \mathrm{~cm}$ above the soil surface. Sample intakes consisted of $0.2 \mu \mathrm{m}$ syringe filters (Acrodisc \#4422, Gelman Scientific) attached to $1 / 8$ in. o.d. copper tubing. The flow rate through each intake was controlled by a needle valve adjusted to limit the flow to $0.71 \mathrm{~min}^{-1}$. Filters were changed and flow rates checked every 10 days or so to prevent clogging by dust. This flow rate was sufficiently small to prevent disruption of the flow near the intakes, yet still provided enough flow to flush the system rapidly after each switching. Polyethylene tubing (5 $\mathrm{m}$ long, $1 / 4$ in. o.d., $1 / 8$ in. i.d.) ran from the needle valves back to three-way solenoid valves (ASCO \#8320G176). When de-energised, these valves directed the flow to the pump by-passing the analyser. When energised, flow was directed to the analyser. This arrangement prevented pressure fluctuations from interfering with the measurement. The solenoid valves were controlled by the computer through relays. Two externally modified driers (Perma-Pure \#PD-1000-48SS) were used to remove water from the 
sample air. Standard error of $\mathrm{N}_{2} \mathrm{O}$ concentration for the $1 \mathrm{~h}$ averaging period was $\pm 0.1 \mathrm{ppbv}$.

\subsection{Data analysis}

Each trial produced about 24 profiles per microplot. All profiles were plotted against the logarithm of height and visually inspected. All profile pairs in which there was a clear difference in $\mathrm{N}_{2} \mathrm{O}$ flux converged only at the highest sample intake, if at all, showing that the lower intakes were well within the footprint of the microplot. Several trials proved to have unsuitable profiles due to a lack of flux (i.e. zero gradient). These trials were omitted from the analysis to avoid the complications of dividing two small numbers. One trial was clearly contaminated by a blocked intake, and so was omitted. Because the intakes over the two microplots were not always at the same heights, profiles were also inspected to determine which points to use in calculating the average gradient to ensure that the ratios were of gradients at the same height. In hindsight, it would have been preferable to ensure that the two sets of intakes were at the same heights when each trial began. For each trial included in the calculations, all measured profiles were used.

Once this primitive data filtering had been done, the gradients were summed over the $24 \mathrm{~h}$ for each microplot and then the ratio of the cumulative gradients calculated for each trial (this is equivalent to the ratio of the mean gradients). In the discussion that follows, each trial will be referred to by its paired treatments: $\mathrm{C}_{2} \mathrm{H}_{2} / \mathrm{CO}_{2}, \mathrm{CO}_{2} /$ control and control/control. Ratios were calculated as just listed, with the control/control trials calculated by Plot $1 /$ Plot 2, where plot number simply refers to the order the data was collected by the computer.

\section{Results and discussion}

Ratios of mean apparent $\mathrm{N}_{2} / \mathrm{N}_{2} \mathrm{O}$ fluxes for the period following fertilisation are listed in Table 1 . These were calculated from Eq. (3) using the sum of the gradients over $24 \mathrm{~h}$. For the various trials, these were calculated as $\mathrm{C}_{2} \mathrm{H}_{2}$ /control, $\mathrm{CO}_{2}$ /control and Plot 1/Plot 2 (where plot number refers to the sampling order used by the control computer). The range of ratios for the control/control trials was $0.70-1.05$, for
Table 1

Summary of trials ${ }^{\mathrm{a}}$

\begin{tabular}{|c|c|c|c|}
\hline Trial & Date & Treatment $^{\mathrm{b}}$ & Cumulative $\mathrm{N}_{2} / \mathrm{N}_{2} \mathrm{O}$ ratio \\
\hline A & 10 September & $\mathrm{C}_{2} \mathrm{H}_{2} / \mathrm{CO}_{2}$ & 31.40 \\
\hline $\mathrm{C}$ & 24 September & & 2.39 \\
\hline $\mathrm{H}$ & 17 October & & 19.69 \\
\hline $\mathrm{J}$ & 19 October & & 0.42 \\
\hline $\mathrm{L}$ & 25 October & & 28.25 \\
\hline $\mathrm{E}$ & 27 September & $\mathrm{CO}_{2} /$ control & 1.44 \\
\hline G & 1 October & & 1.01 \\
\hline $\mathrm{K}$ & 21 October & & 1.52 \\
\hline B & 17 September & Control/control & -0.16 \\
\hline $\mathrm{D}$ & 25 September & & 0.65 \\
\hline $\mathrm{F}$ & 30 September & & 1.05 \\
\hline I & 18 October & & -0.70 \\
\hline
\end{tabular}

${ }^{a}$ Apparent $\mathrm{N}_{2} / \mathrm{N}_{2} \mathrm{O}$ flux also listed, calculated as ratio of cumulative gradients minus one for $24 \mathrm{~h}$ after fertilisation Eq. (3).

$\mathrm{b}$ Treatment refers to type of gas injected, control means no gas injection.

$\mathrm{CO}_{2}$ /control trials 1.01-1.52 and for the $\mathrm{C}_{2} \mathrm{H}_{2} / \mathrm{CO}_{2}$ trials $0.42-31.4$.

The control/control trials show that, on average, little error in implied $\mathrm{N}_{2}$ flux is introduced by the natural variability in $\mathrm{N}_{2} \mathrm{O}$ emissions. The variability would decrease with additional plots and longer averaging times. In contrast, the majority of $\mathrm{C}_{2} \mathrm{H}_{2} / \mathrm{CO}_{2}$ trials showed a huge increase in $\mathrm{N}_{2} \mathrm{O}$ relative to the $\mathrm{CO}_{2}$ plot. Three of these trials had ratios in the range of 20-30, while two showed values comparable to the control trials. The range is due to the natural variability in $\mathrm{N}_{2}$ fluxes from denitrification. The values and ranges shown here are similar to previously reported values for $\mathrm{N}_{2} / \mathrm{N}_{2} \mathrm{O}$ production (e.g., Duxbury, 1986; Stevens and Laughlin, 1998) using both $\mathrm{C}_{2} \mathrm{H}_{2}$ inhibition and isotope methods. The results from the $\mathrm{CO}_{2}$ /control trials do not show a strong effect of the gas injection, however, in each case there is a positive change, suggesting some small increase in $\mathrm{N}_{2} \mathrm{O}$ flux due to mass-flow or oxygen displacement. This result is uncertain given the small number of these trials. Though further work to verify this is desirable, the possible increases are small relative to the $\mathrm{C}_{2} \mathrm{H}_{2}$-induced increases during significant denitrification events.

\section{Conclusions}

This paper has described a method of applying a micrometeorological technique to acetylene inhibition 
studies of denitrification. A TDLTGAS was used to measure four-point profiles over microplots, one with $\mathrm{C}_{2} \mathrm{H}_{2}$ added and one without, enabling an estimate of $\mathrm{N}_{2} / \mathrm{N}_{2} \mathrm{O}$ produced during denitrification. The system proved capable of achieving high resolution of concentration with the requisite low flow rates. The microplots were easily inundated with $\mathrm{C}_{2} \mathrm{H}_{2}$ and we were able to monitor two plots simultaneously. Because the frames were portable, the microplots were readily re-located within the field. By frequently moving the microplots, we avoided the problems of reduced efficacy of the $\mathrm{C}_{2} \mathrm{H}_{2}$ block and $\mathrm{C}_{2} \mathrm{H}_{2}$ blockage of nitrification.

The technique of gradient ratios near the surface could be applied to other questions as well. For example, it could be used in small plot studies of agricultural management practices where a large fetch is not available. It also provides a novel technique for quantifying heterogeneity in trace gas emissions within a single field.

\section{Acknowledgements}

We would like to thank Dr. C. Wagner-Riddle and Mr. R. Sweetman for their help in this work. We gratefully acknowledge the financial support of the Ontario Ministry of Agriculture, Food, and Rural Affairs and the Natural Sciences and Engineering Research Council.

\section{References}

Denmead, O.T., Raupach, M.R., 1993. Methods for measuring atmospheric gas transport in agricultural and forest systems. In: Harper, L.A., Peterson, G.A., Baenziger, P.S., Luxmoore, R.J. (Eds.), Agricultural Ecosystem Effects on Trace Gases and Global Climate Change. American Society of Agronomy Special Publication No.55, Madison, WI, USA, pp. 19-43.

Duxbury, J.M., 1986. Advantages of the acetylene method of measuring denitrification. In: Hauck, R.D., Weaver, R.W. (Eds.), Field Measurement of Dinitrogen Fixation and Dentrification. Soil Science Society of America, Madison, WI, USA, pp. 73-91.

McConnaughey, P.K., Duxbury, J.M., 1986. Introduction of acetylene into soil for measurement of denitrification. Soil Sci. Soc. Am. J. 50, 260-263.

Paul, E.A., Clark, F.E., 1989. Soil Microbiology and Biochemistry. Academic Press, San Diego, CA, USA.

Rolston, D.E., 1986. Limitations of the acetylene blockage technique for field measurement of denitrification. In: Hauck, R.D., Weaver, R.W. (Eds.), Field Measurement of Dinitrogen Fixation and Dentrification. Soil Science Society of America, Madison, WI, USA, pp. 93-101.

Ryden, J.C., Lund, L.J., Letey, J., Focht, D.D., 1979. Direct measurement of denitrification loss from soils: II. Development and applications of field methods. Soil Sci. Soc. Am. J. 43, $110-118$.

Simpson, I.J., Edwards, G.C., Thurtell, G.W., den Hartog, G., Neumann, H.H., Staebler, R.M., 1997. Micrometeorological measurements of methane and nitrous oxide exchange above a boreal aspen forest. J. Geophys. Res. 102, 29331-29341.

Stevens, R.J., Laughlin, R.J., 1998. Measurements of nitrous oxide and di-nitrogen emissions from agricultural soils. Nutr. Cycling Agroecosyst. 52, 131-139. 